University of Nebraska - Lincoln

DigitalCommons@University of Nebraska-Lincoln

Faculty Publications: Department of Teaching, Department of Teaching, Learning and Teacher Learning and Teacher Education

Education

2012

\title{
Good Teaching? An Examination of Culturally Relevant Pedagogy as an Equity Practice
}

Mardi Schmeichel

Follow this and additional works at: https://digitalcommons.unl.edu/teachlearnfacpub

Part of the Curriculum and Instruction Commons, Social and Philosophical Foundations of Education Commons, and the Teacher Education and Professional Development Commons

This Article is brought to you for free and open access by the Department of Teaching, Learning and Teacher Education at DigitalCommons@University of Nebraska - Lincoln. It has been accepted for inclusion in Faculty Publications: Department of Teaching, Learning and Teacher Education by an authorized administrator of DigitalCommons@University of Nebraska - Lincoln. 


\title{
Good Teaching? An Examination of Culturally Relevant Pedagogy as an Equity Practice
}

\author{
Mardi Schmeichel
}

Department of Elementary and Social Studies Education, University of Georgia, Athens, Georgia, USA

\begin{abstract}
The adoption of educational policy measures to close the achievement gap, as well as the significant amount of scholarship dedicated to the subject, are just some of the indicators that reflect the tremendous concern in education about the academic performance of students of color. Within research aimed at promoting equitable practices in education, culturally relevant teaching has emerged as a good teaching strategy to improve achievement. Using genealogical methods to examine the ways in which culture has become relevant to classroom practice, the author argues that the perceived difference from white students that made it possible to conceive of children of color as culturally deficit in the 1960s is also invoked in more recent literature that promotes attending to culture as an equity strategy. The take-up of culturally relevant teaching as something that a teacher can "do," instead of a critical stance that a teacher takes, is also examined and critiqued.
\end{abstract}

Keywords: culturally relevant instruction, race, equity, instruction

I like to start my courses for preservice teachers with a conversation about "good teaching." I have found that the simple exercise of asking students to define good teaching provides a way for them to begin thinking about the complexity of enacting it. Despite their lengthy apprenticeship of observation (Lortie, 1975) or their emerging identities as teachers, they often struggle to come up with a concise description of what good teaching is. In a recent discussion about good teaching, one student stopped and started her explanation several times before finally exclaiming, "It's like what that [U.S.] Supreme Court justice said about pornography: I know it when I see it!"1 However, in an era in which schools, and in particular schools that serve students of color, are seen as "in crisis" (Gates, 2009; Skoll et al., 2010; Dillon, 2011), playing with ideas of what good teaching is may be seen as an indulgent folly. The dissemination of good teaching practices is seen as key to efforts to close 
the achievement gap and to improve the educational experiences of children of color. Culturally relevant pedagogy is one example of good teaching that is promoted as a way to improve the achievement of students of color (Cazden and Leggett, 1976; Ladson-Billings, 1995b; Au, 2009). Culturally relevant teaching is ubiquitous in reform-oriented literature: an ERIC search on the phrase "culturally relevant education" yields more than 1,900 results. There are more than 500,000 hits for the phrase on Google. ${ }^{2}$ For educators concerned with promoting equity, it is taken for granted that culturally relevant teaching is "good teaching." However, how did culturally relevant teaching become an activity that could and should be done for students of color? Post-structural scholars (Lather, 1991; Walkerdine, 1998; Britzman, 2003; Davies, 2003) have argued the value of questioning takenfor-granted "good" practices and assumptions in education in order to unravel ways of thinking, talking, and doing that may be closing down more radical and effective options than the ones available to us now. Taking heed of Lather's (1991) contention that "uncovering the particularity and contingency of our knowledge and practices is at the core of whatever generative advances we might make regarding our purposes and practices" (p. 14), I investigated education literature to understand how the culture of students of color came to be relevant to classroom practice and to consider what systems of reason (Popkewitz, 2009) were invoked to make this kind of thinking possible. The purpose of this work was not to reveal the "truth" about culturally relevant teaching, but to point to the contingency of the accepted wisdom about cultural difference that makes this practice possible and to consider the possibility that the consequences of this kind of good teaching are problematic for those of us concerned with equity. In the next section, I describe the methods I used to explore these issues.

\section{Not your grandmother's genealogy}

In order to understand how culturally relevant teaching emerged as a good teaching practice, I used genealogical methods to study the discourse around children of color in education research. Foucauldian genealogies interrogate the origins of a present truth by making it strange and examining its discursive production in the historical record. This is done by examining texts in the present and following references to a concept, and then references to those references, back to the point at which it becomes possible to see the concept emerging as a coherent idea in the discourse. The exploration then extends beyond that point in order to understand the conditions through which it became possible for the concept to "leap from the wings to centre stage" (Foucault, 1971/1977: 150). For Foucault (1977/1995: 31), genealogy was a means to create a "history of the present," and a framework for investigating and thinking about current concepts in a way that could disrupt the perception that our everyday practices are an inevitable result of a linear series of events. For example, instead of taking the logic of culturally relevant teaching for granted, genealogical work asks how the logic of it has been constructed. Through genealogy, as Meadmore et al. (2000: 464) argued, "the legitimacy of the present can be undercut by the foreignness of the past, offering the present up for examination and further enquiry." Tracing the emergence of a commonsense, "good" practice like culturally relevant teaching causes us to reconsider an idea that we might otherwise see as an inevitable step toward progress. 
Genealogy highlights the historicity and contingency of ideas and practices that we believe are too reasonable to have been engineered - or "in what we tend to feel is without history" (Foucault, 1971/1977: 139).

To understand the production of culturally relevant teaching, it was necessary to examine not only its emergence but also the failures surrounding its production: what was excluded from the theory of culturally relevant teaching and how was it excluded? The attention paid to failures is one of the most significant differences between Foucauldian history and a more traditional historical approach. Where traditional history "aims at dissolving the singular event into an ideal continuity" (Foucault, 1971/1977: 154), Foucault's approach to history "deprives the self of the reassuring stability of life and nature" (p. 154). If traditional history focuses on broad patterns which are "supposedly revelatory of great forces at work" (Prado, 2000: 40), genealogy focuses on the small and incongruent data which disrupt the possibility of seeing the past as coherently, rationally, or purposefully shaped by an imaginary and progressive force. Genealogical work seeks to represent the disjunctures in order to "undermine the solidity of unquestioned rationales and institutional matrices" (Tamboukou and Ball, 2003: 21). By attending to the historical context of practices and ideas as well as the struggles around them, genealogical work can make our everyday assumptions more fragile. The recognition of the fragility of the truth that culturally relevant teaching is good teaching has the potential to make other ways of thinking possible.

This genealogy traces references to culturally relevant education and teaching within the education literature-primarily US education research journals, books, and practitioner publications in the post-segregation era-in order to understand why and how it came to be possible to think of some children as culturally different. Prior to Brown v. Board of Education in 1954, the segregation of the US school system ensured that, for the most part, the cultural issues relevant to the education of African American students were only of marginal interest to white educators. After Brown, and its mandate to integrate schools, a great deal more attention was paid to the culture of children of color in mainstream publications.

\section{Tracing the discourse of difference}

Attempting to describe and analyze all of the literature that addresses students of color or culturally relevant teaching, or to construct a summary of the sources I reviewed while doing this research would be an ill-fated attempt to give illusory shape and order to this discourse. Instead, in the next three sections I will draw attention to several specific pieces of literature that provide a way of thinking about how discourses around the culture of children of color were constructed in the literature, and, more specifically, can demonstrate how these discourses were mobilized to reinscribe difference as the organizing principle upon which to make decisions about good teaching practices. In the first section, I describe ways in which the culture of children of color was positioned as a deficit in comparison to white, middle-class norms. I then highlight literature which framed culture as contributing to differences in the learning and behavior of children of color. In the third section, I provide excerpts from several pieces of the data which point to dissent within the educational 
research community about whether identifying cultural differences to implement culturally relevant practices was something that scholars and educators should or could do.

\section{Difference $=$ deficit}

The concept of cultural deprivation or disadvantage was the frame used to describe children of color within the literature in the years immediately following the Brown decision. Culture was described as the key to understanding what was inhibiting the academic success of children of color: the perceived difference between "mainstream" culture and the culture of children of color was described in terms of a gap that must be filled. Although the link between cultural disadvantage and race was not always explicit in the description of what to do about culturally disadvantaged students, the allusions to the urban and slum communities in which this work was conducted typically included a brief reference, like the following, which described the culturally deprived as "poor Negroes, Puerto Ricans, and other minorities who, for economic and social reasons, are forced to settle in ghetto areas" (Mackler and Elkin, 1967: 129). The absence of explicit descriptions of the specific demographic groups and communities which were being analyzed not only reflected a different conceptualization of what counted as "good" research during this era but also pointed to the ease with which one could talk about students in terms of deprivation and disadvantage as just another way to talk about children of color. Additionally, there seemed to be little interest in making a distinction between concerns about particular cultural groups: rarely, for example, was there a distinction made between the needs of African American students and those of Hispanic students. From the late 1950s through the 1970s, a student was either white or culturally different/deprived/disadvantaged.

The belief that children of different racial groups were inherently different from each other rested on the assumption that white, middle-class behavior and attitudes were typical or normal. Researchers were particularly concerned with the cultural difference of the white, middle-class, female teaching corps and the students of color in their classroom. The interactions between teachers who expected "the norm" and students who were not "the norm" were described as problematic and as contributing to the academic failure of the students of color. For example, Gordon and Wilkerson (1966: 57) argued that "when a teacher understands how the disadvantaged differ from herself and from the children she may have previously taught, she becomes aware of the degree to which her own middle class values inhibit her positive perceptions of and relations with these children." Edwards (1967: 163) described the "problem" as the difference between middle-class educators, who possess a preconception of "The Typical American Student" and the "many students who come from cultural pockets that are quite at variance with the general American culture and who, therefore, require something of a tailor-made curriculum." Because these students weren't typical or a part of the dominant American culture, the kind of curriculum that could address their needs, Edwards argued, would require the educator to take into consideration the "unique characteristics of the 'culturally different' learner."

The key to overcoming these differences was knowledge of how the culture of the deprived student deviated from the norm. Taba and Elkins (1966: 23) posited that it was the teacher's responsibility to gather data about and diagnose culturally deprived children in 
order to avoid "teaching in the dark" with students "whose background, motivation, learning styles, and habits deviate from the usual." Gordon and Wilkerson (1966: 2), in their description of children whose culture "has failed to provide them with experiences that are 'normal' to the kinds of children schools are used to teaching" concluded, "it is quite evident that in order to provide equality of education for disadvantaged children, we must identify the children and characterize the specific nature of their disadvantage. We need to know exactly how these youngsters differ from those with whom our traditional educational system has been successful."

The tone of the articles of the time period was exemplified in a piece from 1963 titled "Our demoralizing slum schools," in which poor, urban families were described as

characterized by material deprivation and low standards of conduct. . . . They are too lazy, drunk, or mentally deficient to care what happens to their children. Demoralized and frustrated out of debauchery or ignorance, they are quick to blame anyone but themselves for their unfortunate situation. (Vontress, 1963: 78)

About the students themselves, the author claimed,

Youngsters no longer able to withstand the confinement of classrooms are roving the streets night and day looking for their kind of excitement-crime and destruction. To them, nothing is inviolable. Incapable of achieving in school . . . stealing, destroying, assaulting, they do not or cannot conform to the expectations of the dominant society. (p. 80)

These stark characterizations of the ways that students of color, and their families, were different from "dominant society" leave no room for considering their cultural differences as positive or as potential resources from which teachers might draw. However, in the next section, I point to some research that positioned cultural differences in another way.

\section{What's deprived about being different?}

There were researchers who advocated for an alternative frame through which to interpret the differences between students of color and white students in public schools. In "What's deprived about being different?" La Belle (1971) accused the cultural-deprivation theorists of elevating middle-class, white culture to the highest position within a hierarchy of cultures that, when communicated to new teachers, promoted a cycle of self-fulfilling prophecy in their classrooms. He called for a distinction between deprivation and difference, and argued that it was imperative that schools take that difference into account through attention to diversity in the staff and student population. La Belle contended that good teachers in an ideal school would,

promote attitudes and behaviour patterns conducive to providing equal opportunity for all pupils ... and would develop its own basal descriptions of attitudes, values, social organization and other ethnic variables that are evident in their 
community ... to learn how a group copes with its environment and how values and attitudes develop as a result of adapting to a given environment. (p. 18)

La Belle also addressed pedagogy, stating, "The teacher would ferret out variations in pupils' conceptual approach to problems. She would realize that cognitive styles are culturally derived rather than universal among men and she would build on the ways in which culturally different groups approach problem-solving" (p. 18). La Belle's work is a rejection of discourse which positioned cultural difference as something that was inherently problematic. Instead, he positioned the good teacher as being responsible for learning about her students' culture and using that knowledge to inform her classroom practice.

Cazden and Leggett (1976) built upon this theme in their argument that it was appropriate to adapt instruction to the learning styles of culturally different children. They used evidence from anthropology and psychology to support their position that the existing research provided at least some indication that there were cultural differences in cognitive style and "interactional" style. For example, their analysis of the research on different auditory strategies indicated that the reliance on verbal expression oppressed the academic performance of students whose ability, "to comprehend or produce the language of instruction is in question" (p. 12). Therefore, they stressed that teachers should implement a variety of instructional strategies to enable all students to learn and demonstrate their understanding.

Additionally, they surveyed research to identify the cognitive styles of different cultural groups. Cazden and Leggett described studies which indicated that Mexican American and African American children relied on social frames of reference and social cues more than white students. They encouraged educators to conduct further empirical research on pedagogical strategies to align with student cognitive styles to improve student performance. They concluded,

Some suggestions for educational practices that should enhance learning for ... children are simply suggestions for better education in general-e.g. providing more structure for curriculum tasks and creating more learning situations which allow for interpersonal interaction. They would be generally considered aspects of good teaching. (p. 18)

Cazden and Leggett explored the ethnographic evidence regarding environments in which students learned and didn't learn through a consideration of "interactional" styles. They cited evidence from one ethnographic study in which Mexican American children were found to be more cooperative than white students and also referred to Philips' (1972) work on the Warm Springs Reservation that found that Native American students preferred cooperative learning groups or individual activities over more teacher-centred strategies. Although Cazden and Leggett were cautious about the generalizabitlity of the early research, and were especially wary of the dangers of applying stereotyped notions of culture to educational settings, they contended 
no one has to wait for formal research results before attempting change. . . . Where participation is low, teachers and supporting personnel ... must diagnose the classroom learning environment (not the children), try alternative participant structures in the light of the general research reviewed above and then monitor the results ... there is probably no more powerful way to create culturally responsive education. (p. 26)

The framing of students as culturally, socially, and economically disadvantaged or advantaged within the context of school was indicative of the emerging possibility of interpreting difference in a positive way. Cazden and Leggett's description of culturally determined cognitive and affective predispositions, and the situating of those differences as functions of the larger cultural contexts from which they emanated, created a space in which it was possible to use anthropological and psychological data to support La Belle's (1971) argument that difference was not deficit. In order to buttress their arguments that teachers could use cultural knowledge to implement "good teaching" in their classrooms, Cazden and Leggett presented scientific evidence of cultural difference, providing validity and justification for the promotion of culturally relevant teaching practices. Despite the absence of a large quantity of research on the cultural differences of children, teachers could at least strive toward culturally relevant practices, they noted, not through diagnosing children, but through a diagnosis of the classroom environment the teachers had created. In addition to a shift toward using evidence-based practices to implement culturally relevant teaching, this work indicated a shift from using cultural knowledge to identify what was wrong with the child to using cultural knowledge in the classroom to implement good teaching practices for children of color for the purpose of improving academic performance.

\section{Using culture to inform practice: Dissent and dissonance}

Because it is a methodology that traces the emergence of a concept in the discourses which precede its adoption as a commonsense idea, genealogical work is particularly useful for identifying discontinuities and dissent around a topic. Within the discourses of cultural deficit and difference, there are numerous examples of scholars who warned against the application of questionable ethnographic scholarship to inform classroom practice. For example, in his 1967 review of the "very uneven body of literature," which represented an intersection of anthropology and education, educational anthropologist Wolcott (1967) stated,

because of the popularity of analysing educational problems and settings from a cultural perspective, many non-anthropologists are contributing to the field, writing about culturally relevant dimensions of behaviour but frequently without anthropological convictions, commitments, or competencies. (p. 83)

Wolcott was particularly concerned about the inconsistent application of anthropological methods and standards to the sphere of education. He felt that this work was being 
pitched to a specific audience and that this orientation was affecting the quality of the research:

The few anthropologists who do focus attention on formal education are not writing for their peers; they are writing to a highly receptive audience of patrons, the professional educators. The audience is so receptive and the number of anthropologists so few that the field is beset by many problems. (p. 82)

Wolcott's indication that there was a thirst in the educational community for the kind of cultural analysis of schools that could help educators address problems reflects a consistent pattern in the scholarship that attends to the experiences of children of color: cultural knowledge was seen as relevant to educators primarily as a resource for attending to crises. That this thirst for cultural analyses led to what Wolcott perceived was subpar ethnographic work not only indicated the complexity of using cultural knowledge in an education setting but also pointed to the possibility that this knowledge could be used in problematic ways.

Concerns about the application of anthropological and ethnographic work in educational contexts were also voiced by other leaders in the field. For example, in a book chapter written for teacher educators, Cazden and Mehan (1989) stated that, because of the cultural differences between most teachers and their students,

we will not be recommending that beginning teachers try to learn details about the culture of different groups . . . this is both impossible and dangerous. It is impossible because there are too many cultures represented in the classroom; it is dangerous because limited knowledge can lead to stereotypes that impede learning. (p. 47)

In their discussion of the "dangers" of attempting to convey to teachers information about the cultures of the students whom they teach, Cazden and Mehan pointed to an incident in New York in 1987, in which the New York State Board of Regents, in an attempt to promote cultural awareness and knowledge for teachers, had circulated a working paper which listed the qualities and characteristics of African Americans. The paper came under attack and was with withdrawn, but Cazden and Mehan used the incident as an example of the likelihood that trying to teach white, middle-class teachers about the culture of the Other would result in promoting "stereotyped categories and labels that then become barriers" (p. 54).

Ogbu (1981: 4) also urged educators to be wary of applying the results of the ethnographic work circulating in the discourse, warning, "many school ethnographers have not had the opportunity of training in traditional ethnographic methods of anthropology. This limitation is made worse by misconceptions and superficial application of ethnographic research." In particular, Ogbu was concerned with microethnography, which had emerged as the method for examining classrooms and schools. He argued that this focus, and the microanalysis of student/teacher interactions, resulted in the centering of classrooms as the causes of failure of students of color without a consideration of the larger social, economic, 
and cultural forces at work outside of the educational context. Although Ogbu acknowledged that ethnographic work in schools had identified the way in which communication patterns could lead to student failure, which debunked the previous cultural deficit models, he felt that the results of microethnographic research could be misleading or overly simplistic. In particular, he posited that "they cannot lead to any significant social change that would eliminate the need for such remedial efforts in subsequent generations of minority-group children" (p. 12). In other words, he argued, the classroom may have been the battlefield but it was not the war, and acting on over-generalized understandings of culture, in the absence of social critique, would not result in improved educational experiences for the children they were intended to benefit.

Villegas (1988) echoed the concern about the need for social critique in her review of sociolinguistic research that examined the home/school language mismatch. She argued that this kind of work reaffirmed "the teacher's capacity to influence students' lives in a positive way" (p. 258) by suggesting that culturally sensitive solutions were available. However, Villegas asserted that by leaving social structures and inequities unexamined, home/school language research "diverts attention away from the social inequalities that sustain the widespread academic failure of minority students" (p. 254). In other words, culturally sensitive language strategies appear to provide "a number of educational 'solutions' that have profound implications for the lives of students, with little attention given to the social implications of those solutions" (p. 259). Villegas went on to argue that teacher education programs have a responsibility to go beyond the promotion and acceptance of cultural difference by also providing preservice teachers with the capacity "to analyse the sociopolitical system that gives rise to those differences" (p. 261). She concluded that "culturally sensitive remedies to the educational problems of oppressed minority students that ignore this political aspect of school are doomed to failure. Worse still, they give the illusion of progress while perpetuating the academic problem" (p. 263).

These excerpts make clear some concerns circulating in the discourse about the complexity of using cultural knowledge to inform classroom practice. Additionally, the illumination of difference without an accompanying critique of social inequalities was identified as a problematic way of preparing educators to teach students of color. Despite these warnings, ethnographic studies of students of color continued to multiply in the 1980s as a way of trying to understand and close the gap between the achievement of white students and students of color. As Levinson and Holland (1996) noted in their commentary regarding that decade, educational anthropologists in the 1980s were busy

distinguish[ing] themselves by contributing to finely detailed accounts of "differences," "discontinuities," "conflicts," and "mismatches" between mainstream school culture and the traditional cultures of racial/ethnic minorities . . . attempting to identify differences between their respective communication patterns, linguistic codes, and kinesic and cognitive styles. (p. 8)

The academy was experiencing what has been dubbed "the multicultural turn," an institutionalization of the study of race and culture resulting from the increasing demand for information about marginalized groups, the increased presence of scholars from these 
groups in academia, and the emergence of specialized ethnic studies departments (Henry, 1995). As official knowledge about difference grew, researchers began to systematically identify and categorize students of color in terms of their learning styles. Although there were some leaders in the field already pointing to the problems inherent in this work, there was enormous momentum behind thinking about students' cultural differences as something that a good teacher must attend to in order to improve the academic achievement of children of color.

\section{The emergence of culturally relevant teaching as an equity strategy}

Scholarship referencing culturally relevant teaching and pedagogy exploded in the late 1980s and early 1990s. It is difficult to find a prominent journal during this time period in which a reference to cultural relevance is not present in some iteration. However, the theory is often attributed to Gloria Ladson-Billings. According to Google Scholar, LadsonBillings's (1994) book on culturally relevant pedagogy, The Dreamkeepers, was cited more than 2,000 times and her American Educational Research Journal article on the same topic, "Toward a theory of culturally relevant pedagogy" (Ladson-Billings, 1995a), was cited 885 times. Although other scholars have written about cultural relevance in pedagogy and education (Gay, 2000, 2010; Howard, 2001, 2003; Irvine and Armento, 2001; Villegas and Lucas, 2002, 2007; Irvine, 2010), Ladson-Billings's work in this area is the most often cited and seemed to form the genesis of the current use of the term.

Ladson-Billings positioned pedagogy at the center of the discussion about what needed to be changed about schools. She argued that the previous research in this area possessed either a cultural congruence or cultural compatibility perspective to analyze the school experiences of students of color. The similarity between these two categories was the identification of teacher/student language patterns as the source of student achievement or failure and their shared focus upon "fixing" students to fit into the existing school structures. These perspectives, which Ladson-Billing identified as deficit approaches, located the source of the problem in the students and their families, and, in doing so, contributed to the continuing cycle of inequity. Ladson-Billings criticized cultural ecological scholars who claimed that African American under-achievement was attributable to a cultural system which did not value education, which she contended was an ahistorical conclusion and another deficit perspective. An additional flaw of this work is that it didn't take into account the issues of power that impacted students. Citing Villegas (1988), Ladson-Billings argued that without consideration of the structural inequity within society and educational institutions, the sociolinguistic analysis could provide only part of the picture of what is going on in the classroom. The next logical step, from Ladson-Billings's perspective, was a theory that could address student achievement and cultural identity affirmation while casting a critical eye upon schools and society in general.

Motivated to identify an alternative perspective through which to understand the experience of African American students in public schools, and building on the research of educational anthropologists who were interested in identifying positive characteristics that African American students brought to the classroom, Ladson-Billings conducted a 3year ethnographic study of successful teachers of African American students in an 
elementary school district in California. In The Dreamkeepers (1994), "Toward a theory" (1995a), and "But that's just good teaching! The case for culturally relevant pedagogy" (1995b), she presented her analysis of the characteristics of those teachers' beliefs about teaching and their students through a framework she labeled "culturally relevant pedagogy." Building upon the conceptualization of a disconnect between home and school culture, and incorporating a critical paradigm, Ladson-Billings (1995a: 474) presented culturally relevant pedagogy as a theory to "produce students who can achieve academically, produce students who demonstrate cultural competence, and develop students who can both understand and critique the existing social order."

Culturally relevant pedagogy created a space in which students could "maintain their cultural integrity while succeeding academically" (Ladson-Billings, 1995a: 476), and cultural critique was foundational to the theory for both students and teachers. LadsonBillings (1995a) argued that "Not only must teachers encourage academic success and cultural competence, they must help students to recognize, understand, and critique current social inequities. This notion presumes that teachers themselves recognize social inequities and their causes" (p. 477). In "But that's just good teaching!" Ladson-Billings contended that, although what she was proposing might be considered "rather routine strategies that are a part of good teaching," her concern was that "so little of [good teaching] seems to be occurring in classrooms populated by African American students" (Ladson-Billings, 1995b: 159). The purpose of attending to culture through a culturally relevant teaching model, then, was to use "good teaching" practices for the specific purpose of responding to structural inequities by helping students of color to achieve academically.

\section{Difference as a system of reason}

The ubiquitous presence and pervasive promotion of culturally relevant teaching, at least within educational research, in the 1990s and after, was an indication that describing children of color as culturally different and taking those cultural differences into consideration in the classroom had emerged as acceptable practices. Understanding of ethnicity and race had come to be located in a particular sphere which, in some ways, sought to disrupt the culturally monolithic discourse which had normalized the US worldview as white and middle class. Ladson-Billings's work came along at a time in which it became possible for the ideas espoused by scholars like La Belle and Cazden and Leggett to finally be taken up. The intersection of a more universal acceptance of the concept of distinct ethnic identities and the increased accountability required for schools to improve the academic performance of students of color made it possible for educators to promote ways in which teachers might approach the children of color in their classrooms differently.

I would argue, however, that seeing children of color as having cultural skills and academic predilections worthy of recognizing and responding to are linked to the discourses of deficit through a shared reliance upon difference as a system of reason. Popkewitz (2009) described systems of reason as historically produced rules and standards that order our practices with children by governing what it is possible for us to think of as true and reasonable. Finding it reasonable to think about children of color as culturally different, and promoting pedagogies which treat them as such, was not inevitable or universally supported, 
as the comments from leaders in the field like Wolcott, Cazden, Ogbu, and Villegas indicate. However, the move to use knowledge of cultural difference to distinguish which students need what to be successful eventually emerged as a reasonable strategy to reduce inequities in the classroom. In doing so, culturally relevant teaching may have become what Popkewitz (2009: 303) dubbed the ironic double gesture: "a reform impuls[e] for equity [which] embodies and produces inequities and exclusions."

Although, for several decades, some researchers have aimed to reframe the conversation about difference by moving away from deficit discourses, the concept of how children of color were different was still on a continuum (Popkewitz, 2002) which made that difference relative to an unspoken someone: their white, middle-class peers or their white, middleclass teachers. While culturally responsive scholars strived to situate that difference positively, their work simultaneously situated white, middle-class beliefs, behaviors, and cultural strategies as the norm, the center of the continuum. Ladson-Billings's motivation to research successful African American students and their teachers adds further complexity to this scenario, as an investigation of successful students necessarily invokes a comparison to unsuccessful African American students, students who are placed even farther away from the norm or center on the continuum. It seems as if focusing on successful African American students didn't change the way that students of color were framed: it just shifted the spotlight to a different spot on a continuum which had been drawn decades before.

Culturally relevant teaching relies upon a system of reason that not only reinscribes children of color as culturally different from white children but that attempts to validate those differences as valuable resources that can be accessed to help children of color to become as successful, presumably, as white children. As such, discourse around culturally different children fixes cultural identity upon students of color, and, in effect, governs the practices that order children, structuring what it is possible for us to think about them and for them to think about themselves, determining what they can and cannot become (Popkewitz, 2009). For example, research that describes African American children as responsive to movement and verve (Carter et al., 2008; Cole and Boykin, 2008) and African American and Hispanic children as more successful in group activities than individual assignments (Waxman et al., 2007; Hurley et al., 2009), may be true about some children in these groups, some of the time. Surely, however, there are some African American and Hispanic children who do not respond positively to these pedagogies as well as some white children who do. By arguing that students of color possess cultural norms to which teachers can and should respond, membership in a cultural group, which in the US is almost always linked to the color of one's skin, fixes an identity on its members. Using the "truth" about culture to link a particular learning style with race, teachers need only look at their students to know who they are and how to teach them (Parks, 2007). As Butler (1992: 15-16) argued, "Identity categories are never merely descriptive, but always normative, and as such, exclusionary." What happens, then, when an African American student fails to respond to strategies that have been designed to complement her culture? Does this make her less than African American? Has she been, to use a familiar term, culturally deprived, if she doesn't share an interest in classroom activities planned with her cultural group in mind? Popkewitz (2009: 305) argued that "maps that target populations for rescue are also boundaries that differentiate, divide, and cast out particular kinds of humans into 
unlivable spaces." By fixing an identity upon the students, culturally relevant discourses are another source of a potential mismatch between the student and the strategies used in the classroom through the imposition of "a single, drastically simplified group identity that denies the complexity of people's lives, the multiplicity of their identifications and the cross pulls of their various affiliations" (Fraser, 2008: 133). In other words, the more categories we insist that children inhabit and the more expectations we create for them to fulfil, the fewer possibilities we give them to be different (Parks, 2007).

The emergence and acknowledgment of cultural difference within education has also made it possible for federal No Child Left Behind (NCLB) policies in the US to be perceived in terms of racial/ethnic subgroups. In order to address historical inequities and to narrow the achievement gap between African American, Hispanic, and Native American students and their white peers, NCLB requires schools to disaggregate the standardized test performance of their students by racial category, reinscribing difference and making race the explanation for the achievement gap (Parks, 2009). Although test result disaggregation was promoted as a necessary effort to improve the academic achievement of children of color, the side-by-side comparison of students of color to white students creates a space that reinscribes a comparative difference, deficit, and deficiency. As a policy, the disaggregation of test results by race closes down new and potentially more efficacious ways of thinking about students of color.

My intent here is not to reject the belief that participation in cultural groups can and does result in behaviors that can be traced back to group membership, or to argue that there are not "real" differences among students of different racial groups in terms of test results. However, I would like to disrupt the ease with which educators might apply their "knowledge" of the culture of the Other when planning their pedagogy or when interpreting disaggregated test data. As Butler (1992: 17) posited, "To call a presupposition into question is not the same as doing away with it; rather, it is to free it up from its metaphysical lodgings ... [providing] the conditions to mobilize the signifier in the service of an alternate production." In other words, my intention is not to deny that cultures exist and may impact learning and success in school, but to ask what might be possible if we thought about our students and culture in a different way.

By examining the attention to culture within education discourse, it becomes possible to understand how language that positioned children of color as culturally deficit in comparison to white children shifted over time to frame them as culturally different. The emergence of culturally relevant teaching sought to sustain this emphasis of difference over deficit, and was an attempt to address the structural inequities which perpetuated the need for teachers to attend to the different needs of children of color. Through culturally relevant pedagogy, the "play of differences" (Meadmore et al., 2000: 472) between children of color and white children has become a constitutive force which shapes pedagogy and equity work in particular ways. In the next section, I describe two different ways culturally relevant pedagogy has been shaped within recent literature. First, I discuss scholarship which addresses the obstacles to culturally relevant teaching and frames its take-up as difficult and flawed. Then, I present examples of literature that demonstrate the potentially problematic applications of culturally relevant teaching. 


\section{The troubling take-up of culturally relevant teaching}

Recent research has pointed to the difficulty of enacting culturally relevant pedagogy. Young (2010) found in her study of the implementation of culturally relevant pedagogy in an urban school that teachers' cultural bias and the absence of race consciousness inhibited the implementation of culturally relevant practices. In their review of the empirical research describing teachers' implementation of culturally relevant pedagogy, Morrison et al. (2008) also pointed to the obstacles to enacting culturally relevant strategies, such as teachers' inability to implement culturally relevant pedagogy in light of large class sizes, inadequate support, and an emphasis on standardized testing. Additionally, Irvine (2010: 58), chided "well-meaning educators [who] often assume that culturally relevant pedagogy means simply acknowledging ethnic holidays, including popular culture in the curriculum, or adopting colloquial speech," and predicted that attempting to implement culturally relevant teaching in this way can result in "awkward classroom moments, ineffective instructional practices, and counterproductive teacher-student and teacher-parent relationships."

Ladson-Billings (2006: 30) has also weighed in on the current state of culturally relevant teaching. In a book chapter titled, "Yes, but how do we do it? Practicing culturally relevant pedagogy," she argued that in terms of teaching students of color, the problem is not "what to do" but rather "how we think." She stressed that the difference between deficit-oriented pedagogy and the more liberatory approach that teachers might adopt is based upon not only how teachers think about their students but how teachers think about society: "Teachers who I term culturally relevant assume that an asymmetrical (even antagonistic) relationship exists between poor students of colour and society" (Ladson-Billings, 2006: 30). Ladson-Billings noted that in fields like medicine and social work, the idea of cultural competence is perceived as a skill set that enables dominant group members to read the cultural messages of their clients more skillfully, which can result in practices that "reflect a static and essentialized view of culture and tend to reinforce stereotypes" (p. 36). She argued that her promotion of cultural competence was geared toward improving students' lives rather than making teachers "feel better about themselves" (p. 36). Culturally relevant teaching is, in this sense, an "ethical position" (p. 40) that teachers must assume, not a predetermined set of strategies that work with "these" kids. This concern about the direction of culturally relevant pedagogy was also reflected in a 2008 American Educational Research Association (AERA) presentation in which both Irvine and Ladson-Billings participated, titled "Reclaiming culturally relevant and responsive pedagogy: historical dimensions and future directions" (American Educational Research Association, 2008: 68; emphasis added).

However, the very aspects of the current discourse of culturally relevant teaching of which Ladson-Billings and her colleagues have been most critical have been the most frequently taken up in educational literature. For example, in much of the work drawing upon culturally relevant teaching theory, descriptions of teacher behavior promoted by culturally relevant theorists have emerged as more salient characteristics of culturally relevant teaching than the critical analysis of society which was the cornerstone of the theory. Within practitioner journals in particular, culturally relevant teaching has been promoted 
not as a critique of inequitable social structures but as a new source of lesson plans or classroom activities.

For example, an article featured in the Research Matters section of a recent issue of The English Journal, a publication intended for English and language arts teachers, is indicative of this watered down approach to culturally relevant teaching. In this piece, the author recounted her experiences coming to teach in a predominately African American high school after having had "primarily worked with white students" in her first school, noting that "coming from a white, middle-class background, like many teachers in this country, I was unprepared for how to reach, teach, and discipline students of color" (Scherff, 2005: 97). She stated that among other surprises, she was shocked by the students' clothing and mannerisms, and was "ill-equipped to handle the storytelling, jokes, and wordplay of the students [because] in my previous 'white' classroom these were rare" (p. 98). In light of the differences she encountered between teaching white students and African American students, the author encouraged fellow English teachers to consider the research on creating culturally responsive classrooms because as teachers who work with language, "we have the power to affirm students and improve their lives" (p. 98). To support her argument about the efficacy of culturally responsive approaches, the author presented an excerpt from a research study (Monroe and Obidah, 2004), which showcased the language an African American teacher used to manage her classroom effectively. Ms. Simpson, the African American teacher described in the study, is quoted as telling the students in her class, who are also African American, that if they are having a bad day and are going to "act the fool" or "snap," they should just let her know beforehand and she will let them go somewhere else. This incident is positioned as an example of the way language can be used in the classroom in a culturally responsive manner. Although the author does not indicate the specific language to which she is referring in her positive analysis of the way that Ms. Simpson was "able to speak" to her students, the implication is that by using phrases such as "act the fool" and "snap," Ms. Simpson has communicated in a way that is culturally responsive to her students. The author then described her own experiences with learning to alter her language when interacting with students in order to avoid potential discipline problems, noting that

going through college, it never crossed my mind that I would use "non-Standard" English in the classroom.... However, by learning to adapt my language, when needed, to fit the culture of the school and community, I developed a better relationship with the students. They enjoyed the class more, and I had fewer discipline problems. (p. 98)

By using white students as a point of contrast, and thereby invoking an unspoken system of reason in which difference can be assumed, this author has reinscribed whiteness as a norm against which to compare students of color. The argument that language like "act the fool" or other "non-Standard English" can be used by white teachers to improve their relationships with African American students is exactly the kind of dangerous application of thin cultural stereotypes that Cazden and Mehan (1989) warned against. Although the author is clearly communicating a concern about the presence of inequity in schools, 
there is an absence of social critique in this take-up of culturally relevant pedagogies. That this article appears in the Research Matters section of this practitioner publication is an indication of how the theory and research on culturally relevant teaching is being translated and taken up in classroom practice.

Similarly, a recent article in the Research and Practice section of Social Education, ${ }^{3}$ titled "Isn't culturally responsive instruction just good teaching?", draws upon notions of difference and avoids social critique in its promotion of culturally relevant instruction. For example, the author presents a table outlining the difference between "mainstream" and "diverse" values. "Mainstream" values include individual effort, competition, personal achievement, and success measured in material terms. "Diverse" values include working with others, cooperation, well-being of the group, and success measured in spiritual terms $(\mathrm{Au}, 2009: 180)$. Who counts as "mainstream" or "diverse" is not articulated explicitly, but because this information is described as being offered in response to frequently expressed concerns about teaching in an "urban school" with students from "different cultural and linguistic backgrounds" (p. 179), the system of difference between white students and the Other is invoked inexplicitly. Additionally, this article fails to acknowledge that culturally relevant teaching requires that teachers possess a critical stance toward the social forces that create inequity. The author assured readers that there is research to indicate that teachers with "mainstream" backgrounds can "successfully use culturally responsive instruction and teach students of diverse backgrounds" (p. 180), but she does not assert, as the majority of culturally relevant scholars do, that in order to enact culturally relevant pedagogy, teachers must be willing and able to critique society. Although this article is geared toward readers who have a concern for students whose culture is different than their own, the presentation of a simple table to outline complex, situated, and contingent cultural characteristics that a student may or may not demonstrate at any given time does not seem to be the kind of thinking about culture that will result in "good teaching" for students of color.

\section{"Everything is dangerous" (Foucault, 1997: 256)}

The concept of culturally relevant teaching is neither inherently good or bad. By considering the context in which it became possible to conceive of students of color as being culturally different from white students, and then exploring how educators became invested in using that understanding to address education inequities, my goal is to disrupt the notion that the way we think about culture as being relevant to the classroom is innocent. Using culture as the basis for equitable pedagogical strategies was not inevitable. In fact, we can hear the warnings as this way of thinking emerged that it could be more harmful than helpful to inscribe cultural difference onto children. The explosion of cultural relevance literature published since the early 1990s, and the lack of a critique of the concept from those with equity-oriented perspectives, indicates that perhaps it is now impossible to think of culturally relevant practices as something that might be "not good teaching." However, the take-up of culture-and therefore, race-outside of an active engagement with racism (Fine and Weiss, 2002) could be a wolf parading in equity's clothing. 
The shifts over time, from descriptions of African Americans as lazy and mentally deficient to discussions of thriving and capable African American students might be perceived as progress, but this genealogical work proposes that the way culturally relevant teaching has been enacted shows that our current thinking about children of color is still based upon a system of difference and still situated within an uncritical paradigm in which educators' reflection upon social injustice is extraneous. Although culturally responsive scholars have situated students of color positively within their critique of schools, educators who raise the culturally relevant teaching banner can claim to be doing equity work without having to consider inequity, and their roles in perpetuating it.

This genealogy offers one way of thinking about how the emergence of culturally relevant teaching, and its reliance upon difference to categorize children, can be traced. The discourse around culturally relevant teaching is replete with discontinuities, shifts, and breaks, and, as a result, there could be other, contradictory ways of looking at the same issue. Tamboukou (1999: 214) argued that "In posing genealogical questions, one can never be sure that one could ultimately find any satisfactory answers. This is the risk, the adventure and the fascination of the exercise." Critiquing an equity strategy is risky: in doing so, I am in danger of appearing to align myself with those who would deny the incredibly unjust and inequitable ways in which students of color experience the educational system. The danger I encounter, however, speaks to the new "regime of truth" (Foucault, 1977: 133) in educational research, a regime in which equity strategies can appear to be too sacred to question. Equity reforms, however, are not inherently liberatory or efficacious. Reforms, even those intended to improve the lives of students who have been systematically marginalized, need to be examined and disturbed, in order to question whether or not we are reinscribing the same unjust discourses that have gotten us here in the first place, because, as Foucault (1988: 155) stated, "a transformation that would remain in the same mode of thought, a transformation that would only be a certain way of better adjusting the same thought of the reality of things, would only be a superficial transformation." If, by relying upon a system of difference, culturally relevant teaching is a superficial transformation of thinking about culture that sticks children of color within the same deficit mode of thought in which they were positioned in the 1960s and 1970s, those of us committed to equity need to be able to talk about it. However, until we can discuss openly the dilemmas within and around this equity strategy, and other attempts to transform classrooms into more equitable places, the time and space that is opened up in journals and schools for the promotion of culturally relevant pedagogy may be giving us permission to not pursue more critical and effective ways of good teaching.

\section{Notes}

1. For a discussion of this reference, see Gerwitz (1996).

2. This article includes a word which is or is asserted to be a proprietary term or trademark. Its inclusion does not imply it has acquired for legal purposes a nonproprietary or general significance, nor is any other judgment implied concerning its legal status.

3. An American practitioner publication for social studies educators. 


\section{References}

American Educational Research Association (2008) 2008 Annual meeting program. Available online at: http://www.aera.net/uploadedFiles/Meetings_and_Events/2008_Annual_Meeting/Annual_Meet ing_Program/16c\%20Monday\%20Afternoon.pdf, accessed September 1, 2010.

$\mathrm{Au}, \mathrm{K}$. (2009) Isn't culturally responsive instruction just good teaching? Social Education, 73(4), 179-183.

Britzman, D. P. (2003) Practice makes practice, 2nd edn (New York, NY: New York University Press).

Butler, J. (1992) Contingent foundations: Feminism and the question of "Postmodernism." In J. Butler and J. Scott (eds), Feminists theorize the political (New York: Routledge), 3-21.

Carter, N. P., Hawkins, T. N. and Natesan, P. (2008) The relationship between verve and the academic achievement of African American students in reading and mathematics in an urban middle school. Educational Foundations, 2(1), 29-46.

Cazden, C. B. and Leggett, E. L. (1976) Culturally responsive education: A response to LAU Remedies II, National Conference on Research Implications of the Task Force Report of the U.S. Office of Civil Rights, U.S. Department of Health, Education and Welfare, 1-36.

Cazden, C., and Mehan, H. (1989) Principles from sociology and anthropology: Context, code, classroom and culture. In M. Reynolds (ed.), Knowledge base for the beginning teacher (Oxford, UK: Pergamon), 47-57.

Cole, J. M., and Boykin, A. W. (2008) Examining culturally structured learning environments with different types of music-linked movement opportunity. Journal of Black Psychology, 34(3), 331-355.

Davies, B. (2003) Frogs, snails, and feminist tales, 2nd edn (Creskill, NJ: Hampton Press).

Dillon, S. (2011, March 9). Most public schools may miss targets, education secretary says. The New York Times. Available online at: http://www.nytimes.com/2011/03/10/education/10education.html, accessed March 7, 2011.

Edwards, T. (1967) Pedagogical and psycho-social adjustment problems in cultural. In J. Hellmuth (ed.), Disadvantaged child. Vol. 1: Special child (Seattle, WA: Seguin School), 161-171.

Fine, M., and Weiss, L. (2002) Writing the "wrongs" of fieldwork: Confronting our own research/ writing dilemmas in urban ethnographies. In N. K. Denzin and Y. S. Lincoln (eds), The qualitative inquiry reader (Thousand Oaks, CA: Sage Publications), 267-297.

Foucault, M. (1977) [1971] Nietzsche, genealogy, history. In D. Bouchard (ed.), Language, countermemory, practice: Selected essays and interviews (Ithaca, NY: Cornell University Press), 139-164.

Foucault, M. (1977) Truth and power. In C. Gordon (ed.), Power/Knowledge: Selected interviews and other writings, 1972-1977 (New York: Pantheon), 109-133.

Foucault, M. (1988) Practicing criticism. In L. D. Kritzman (ed.), Politics, Philosophy, Culture: Interviews and Other Writings, trans. A. Sheridan (New York: Routledge), 152-158. (Reprinted from Liberacion, May 1981, 30-31)

Foucault, M. (1995) [1977] Discipline and punish: the birth of the prison, trans. A. Sheridan (New York: Vintage Books).

Foucault, M. (1997) On the genealogy of ethics: An overview of work in progress. In P. Rabinow (ed.), Ethics: Subjectivity and truth. The essential works of Michel Foucault, 1954-1984, Vol. 1 (New York, NY: The New Press), 1-2, 253-280.

Fraser, N. (2008) Rethinking recognition: Overcoming displacement and reification in cultural politics. In K. Olson (ed.), Adding insult to injury: Nancy Fraser debates her critics (London: Verso), 129-141. 
Gates, B. (2009, July) Remarks. Speech presented at the National Conference of State Legislatures, Philadelphia, PA. Available online at: http://www.gatesfoundation.org/speeches-commentary/ Pages/bill-gates-2009-conference-state-legislatures.aspx\#, accessed March 7, 2011.

Gay, G. (2000) Culturally responsive teaching: theory, research, and practice, 1st edn (New York: Teachers College Press).

Gay, G. (2010) Culturally responsive teaching: theory, research, and practice, 2nd edn (New York: Teachers College Press).

Gerwitz, P. (1996) On "I know it when I see it." The Yale Law Journal, 105(4), 1023-1047.

Gordon, E. W., and Wilkerson, D. A. (1966) Compensatory education for the disadvantaged; programs and practices, preschool through college (New York: College Entrance Examination Board).

Henry, P. (1995) Sociology: After the linguistic and multicultural turns. Sociological Forum, 10(4), 633-652.

Howard, T. C. (2001) Telling their side of the story: African-American students' perceptions of culturally relevant teaching. Urban Review, 33(2), 131-149.

Howard, T. C. (2003) Culturally relevant pedagogy: Ingredients for critical teacher reflection. Theory into Practice, 42(3), 195-202.

Hurley, E. A., Allen, B. A., and Boykin, A. W. (2009) Culture and the interaction of student ethnicity with reward structure in group learning. Cognition and Instruction, 27 (2), 121-146.

Irvine, J. J. (2010) Culturally relevant pedagogy. Education Digest: Essential Readings Condensed for Quick Review, 75(8), 57-61.

Irvine, J. J., and Armento, B. J. (2001) Culturally responsive teaching: lesson planning for elementary and middle grades (Boston: McGraw-Hill).

La Belle, T. J. (1971) What's deprived about being different? Elementary School Journal, 72(1), 13-19.

Ladson-Billings, G. (1994) The Dreamkeepers: Successful teachers of African American children (San Francisco: Jossey-Bass).

Ladson-Billings, G. (1995a) Toward a theory of culturally relevant pedagogy. American Educational Research Journal, 32(3), 465-491.

Ladson-Billings, G. (1995b) But that's just good teaching! The case for culturally relevant pedagogy. Theory into practice, 34(3), 159-165.

Ladson-Billings, G. (2006) Yes, but how do we do it? Practicing culturally relevant pedagogy. In J. Landsman and C. W. Lewis (eds), White teachers, diverse classrooms: A guide to building inclusive schools, promoting high expectations, and eliminating racism (Sterling, VA: Stylus Pub), 29-42.

Lather, P. (1991) Getting smart: feminist research and pedagogy within the postmodern (New York: Routledge).

Levinson, B., and Holland, D. (1996) The cultural production of an educated person: An introduction. In B. Levinson, D. Foley and D. Holland (eds), The cultural production of an educated person (Albany, NY: State University of New York Press), 1-54.

Lortie, D. (1975) Schoolteacher (Chicago: The University of Chicago Press).

Macklin, B., and Elkin, P. (1967) Urban education in the North. In J. Hellmuth (ed.), Disadvantaged child. Vol. 1: Special child (Seattle, WA: Seguin School), 127-138.

Meadmore, D., Hatcher, C., and McWilliam, E. (2000) Getting tense about genealogy. International Journal of Qualitative Studies in Education (QSE), 13(5), 463-476.

Monroe, C. R., and Obidah, J. E. (2004) The influence of cultural synchronization on a teacher's perceptions of disruption. Journal of Teacher Education, 55(3), 256-268.

Morrison, K. A., Robbins, H. H., and Rose, D. G. (2008) Operationalizing culturally relevant pedagogy: A synthesis of classroom-based research. Equity and Excellence in Education, 41(4), 433-452.

Ogbu, J. (1981) School ethnography: A multilevel approach. Anthropology and Education, 12(1), 3-29. 
Parks, A. N. (2007) Discursive possibilities: Re-imagining reform and equity in elementary mathematics. Unpublished dissertation (Michigan State University, East Lansing).

Parks, A. N. (2009) Metaphors of hierarchy in mathematics education discourse: The narrow path. Journal of Curriculum Studies, 42(1), 79-97.

Philips, S. (1972) Acquisition of rules for appropriate speech usage. In C. Cazden, D. Hymes and V. John (eds), The functions of language in the classroom (New York, NY: Teachers College Press), 370-394.

Popkewitz, T. S. (2002) How the alchemy makes inquiry, evidence, and exclusion. Journal of Teacher Education, 53(3), 262-267.

Popkewitz, T. S. (2009) Curriculum study, curriculum history, and curriculum theory: The reason of reason. Journal of Curriculum Studies, 41(3), 301-319.

Prado, C. (2000) Starting with Foucault: An introduction to genealogy (Boulder, CO: Westview Press).

Scherff, L. (2005) Culturally responsive frameworks for teaching. English Journal, 94(4), 97-101.

Skoll, J., Weyermann, D. (producers), and Guggenheim, D. (director) (2010) Waiting for superman [motion picture] (United States: Electric Kinney Films).

Taba, H., and Elkins, D. (1966) Teaching strategies for the culturally disadvantaged (Chicago: Rand McNally).

Tamboukou, M. (1999) Writing genealogies: An exploration of Foucault's strategies for doing research. Discourse: Studies in the Cultural Politics of Education, 20(2), 201-217.

Tamboukou, M., and Ball, S. (2003) Genealogy and ethnography: Fruitful encounters or dangerous liaisons? In M. Tamboukou and S. Ball (eds), Dangerous encounters: genealogy and ethnography (New York, NY: Peter Lang), 1-36.

Villegas, A. M. (1988) School failure and cultural mismatch: Another view. Urban Review, 20(4), 253-265.

Villegas, A. M., and Lucas, T. (2002) Preparing culturally responsive teachers: Rethinking the curriculum. Journal of Teacher Education, 53(1), 20-32.

Villegas, A. M., and Lucas, T. (2007) The culturally responsive teacher. Educational Leadership, 64(6), 28-33.

Vontress, C. E. (1963) Our demoralizing slum schools. Phi Delta Kappan, 45(2), 77-80.

Walkerdine, V. (1998) Counting girls out: Girls and mathematics (London, UK: Routledge-Falmer).

Waxman, H. C., Padron, Y. N., and Garcia, A. (2007) Educational issues and effective practices for Hispanic students. In S. Paik and H. Walberg (eds), Narrowing the achievement gap (New York: Springer), 131-151.

Wolcott, H. (1967) Anthropology and education. Review of Educational Research, 37(1), 82-95.

Young, E. (2010) Challenges to conceptualizing and actualizing culturally relevant pedagogy: How viable is the theory in classroom practice? Journal of Teacher Education, 61(3), 248-260.

\section{About the Author}

Mardi Schmeichel is a doctoral candidate in social studies education in the Department of Elementary and Social Studies Education at the University of Georgia, 629 Aderhold Hall, Athens, GA, 30602, USA, email mardi@uga.edu. Her interests center on poststructural theory and identity in education. 